\title{
Desain, Manufaktur dan Uji Kinerja Mesin Pengolah Serbuk Jahe Merah
}

\author{
Mirza Yusuf*, Ferriawan Yudhanto, Dimas Pulung Purbajati \\ Program Studi Teknologi Mesin, Program Vokasi, Universitas Muhammadiyah Yogyakarta \\ Jl. Lingkar Selatan, Tamantirto, Kasihan, Bantul \\ *Penulis korespondensi: mirza@umy.ac.id
}

Histori artikel: diserahkan 28 Maret 2021, direviu 30 Maret 2021, direvisi 02 April 2021

\begin{abstract}
Design of the red ginger powder production machine aims to increase UMKM (Usaha Mikro Kecil dan Menengah) in the Yogyakarta area. By making a semiautomatic red ginger powder machine, it can increase production capacity and improve the economy for UMKM. Component design is divided into 3 processes, namely; designing the frame, designing the stirring shaft, and designing the cooking tank. There are first adjusted to the design that has been made using the solid works software which is then applied by assembling other components. The drive system on the powdered red ginger production machine uses an AC electric motor which is then forwarded into the v-belt transmission then the output from the transmission is forwarded to the stirring shaft.
\end{abstract}

Keywords: UMKM, design, solidwork, drive system

DOI : https://doi.org/10.18196/jqt.v2i2.11573

WEB : https://journal.umy.ac.id/index.php/qt/article/view/11573

\section{PENDAHULUAN}

Penelitian oleh Setyaningrum et al. (2000) tentang rancang bangun alat produksi 'Bandrek' untuk mengoptimalkan proses kristalisasi dan meminimalkan adanya residu pada produk. Penelitian ini berisi tentang proses pengkristalan serbuk bandrek manual pada UMKM (Usaha Menengah Kecil dan Mikro) Ayuk di dusun Mangun, Limbangan, mengakibatkan kelelahan pekerja dan menghasilkan residu sebanyak $40 \%$ berupa gumpalan kristal besar menyerupai permen. Residu dihasilkan pada kondisi suhu pemasakan $85-90^{\circ} \mathrm{C}$ dan kecepatan aduk $40 \mathrm{rpm}$ dengan tenaga manusia kurang efektif menghasilkan 50\% residu bandrek. Berdasarkan permasalahan tersebut peneliti merancang alat pengkristal bandrek menggunakan desain eksperimen Taguchi untuk mencapai kondisi ideal guna meminimalkan residu dan mengurangi kerugian secara kuantitatif. Hasil yang diperoleh yaitu pada pemanasan optimum di $95-100^{\circ} \mathrm{C}$ dengan putaran dengan mesin sebesar $80 \mathrm{rpm}$ diperoleh hasil residu bandrek lebih kecil yaitu sebesar $20 \%$ sehingga efesiensi produk naik sebesar $30 \%$.
Hariyanto et al. (2020) melakukan perancangan mesin extruder untuk pemnfaatan ubi kayu menjadi makanan tradisional yaitu Lanting. Perancangan mesin meliputi desain alat menggunakan software Autodesk Inventor 2020. Hasil perancangan tersebut menghasilkan produksi lanting dengan kapasitas ubi kayu sebesar $40 \mathrm{Kg} / \mathrm{Jam}$. Perancangan mesin perajang ubi kayu untuk produksi makanan juga pernah dirancang dengan menggunakan pendorong pegas untuk meningkatkan efesiensi produksi ubi kayu sebagai makanan ringan keripik singkong (Yudha et al., 2020). Perancangan desain mesin tersebut dilakukan dengan menggunakan software yang sama yaitu software Autodesk Inventor 2012. Software ini juga dapat menganalisis tegangan dan beban yang terjadi pada rancangan rangka produk (Efendi et al., 2020)

Menurut Yulianto et al. (2018) proses produksi pembuatan serbuk jahe instan dengan metode kristalisasi dapat meningkatkan perekonomian warga RW .05 Kelurahan Tembalang, Semarang yang berisi tentang bagaimana cara mengolah ekstrak jahe menjadi jahe serbuk, dalam proses 
kristalisasi. Penelitian tersebut menggunakan alat yang dinamakan dengan crystallizer.

Crystallizer adalah alat yang digunakan untuk memperoleh atau membuat kristal dari larutannya. Oleh karena itu, larutan yang akan dikristalisasi harus dibuat lewat jenuh terlebih dulu dengan jalan penguapan atau pendinginan. Kristalisasi tidak dapat terjadi tanpa saturasi terlebih dahulu. Cara memperoleh saturasi ini tergantung dari kelarutannya. Tujuan dari penelitian ini adalah merancang dan membuat alat pengolahan serbuk Jahe merah. Adapun metode penelitian yang digunakan adalah rimpang Jahe merah. Alat pemarut berfungsi memarut jahe merah sebelum dimasukkan ke dalam alat Pengolah Serbuk Jahe (PSJ) atau alat rekristalisasi cairan menjadi serbuk. Alat PSJ ini memerlukan beberapa tahapan olahan yang terpadu sehingga dapat meningkatkan nilai jual produk tersebut. Teknologi tepat guna yang diterapkan pada mesin Kristalisasi atau PSJ yaitu pengaduk yang berputar dipadu tabung pemasakan yang diberi pemanas kompor menjadi salah satu solusi dalam pengembangan UMKM tersebut.

\section{Proses Pembuatan Serbuk Jahe}

Secara umum proses pembuatan serbuk jahe dilakukan secara tradisional, proses pembuatan secara manual tentu memiliki kelemahan, diantaranya adalah kurang memperhatikan faktor-faktor yang mempengaruhi kualitas produk jahe merah serbuk. Menggunakan tenaga manusia tentu memerlukan usaha lebih untuk mengaduk cairan ekstrak jahe selama 90180 menit. Putaran saat mengadukpun tidak stabil maka dapat mengakibatkan cairan ekstrak jahe menjadi karamel dan tidak bisa menjadi serbuk karena partikel karbohidrat (pati, Dekstrin, sukrosa), lipida (tristearin, asam stearat, monogliserida, digliserida), protein (gluten, kasein, gelatin, albumin) akan rusak.

Minuman instan dibuat dengan menggunakan teknik enkapsulasi yaitu dengan mengekstrak zat dalam rimpang (oleoresin), kemudian dilarutkan dalam zat padat/solid sebagai carrier. Bahan yang dapat dijadikan bahan carrier (dinding kapsul) adalah golongan gum (karagenan), karbohidrat (pati, Dekstrin, sukrosa), lipida (tristearin, asam stearat, monogliserida, digliserida), protein (gluten, kasein, gelatin, albumin).

\section{METODE}

Langkah kerja mesin Pengolah Serbuk Jahe (PSJ) untuk jenis jahe merah adalah sebagai berikut:

Pada saat motor listrik dihubungkan pada aliran listrik maka putaran dari motor listrik akan diteruskan pada input transmisi melalui pulley dan $v$-belt, kemudian output dari transmisi diteruskan ke putaran poros pengaduk melalui gear dan sprocket. Putaran dari poros pengaduk kemudian di transmisikan ke dalam tabung pemasakan sehingga cairan ekstrak jahe dapat diaduk dan langkah terakhir yaitu panas dari kompor diteruskan kedalam tabung pemasakan.

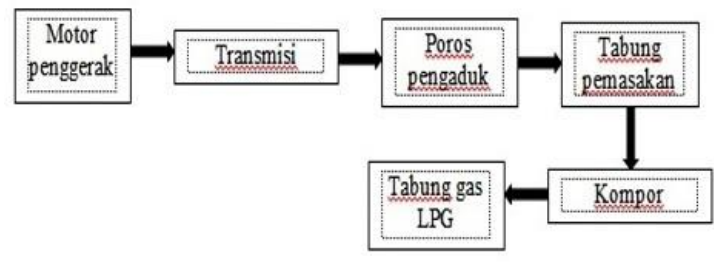

GAMBAR 1. Diagram alir proses

\section{HASIL DAN PEMBAHASAN}

\section{Desain Alat}

Sebelum manufaktur diperlukan desain yang dapat mewakili gambaran umum dari sebuah mesin. Acuan desain tersebut dapat dilakukan dengan melakukan analisis awal untuk meminimalisir kesalahan maupun gagal fungsi. Hasil desain tersebut ditampilkan pada Gambar 2 untuk pandangan dua dimensi (2D) dan Gambar 3 untuk pandangan secara tiga dimensi (3D);

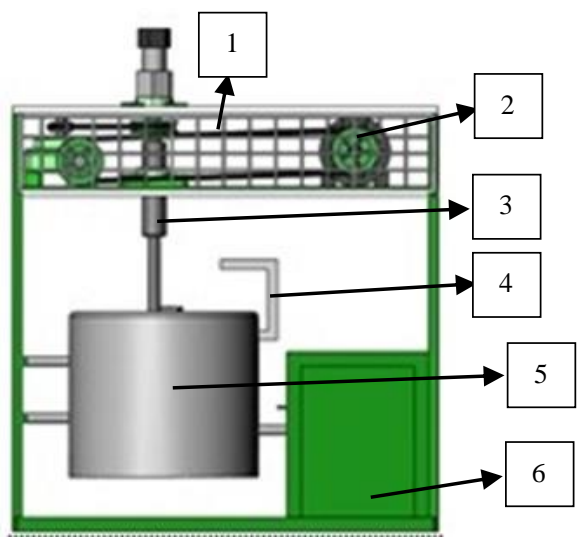

GAMBAR 2. Alat PSJ (Pengolah Serbuk Jahe dengan tampilan 2D) 
Keterangan gambar:

1. V-Belt

2. Pulley diameter 4 inchi

3. Poros pengaduk (diameter $1,75 \mathrm{~cm}$ dan tinggi $30 \mathrm{~cm}$ )

4. Pegangan (handle)

5. Tangki pemasakan (diameter $42 \mathrm{~cm}$ dan tinggi $40 \mathrm{~cm}$ )

6. Tempat tabung gas $3 \mathrm{Kg}$ dan pemanas

Pemasangan sabuk v-belt dan pulley memiliki keunggulan yaitu mudah dalam aplikasi penggunaan, dan memiliki harga relatif lebih murah dibandingkan dengan penggunaan rantai (chain). Kekurangan v-belt yaitu karena menghubungkan dua pulley dengan jarak yang cukup panjang atau dengan gearbox sehingga mudah terjadinya slip (Febrianie et.al., 2018).

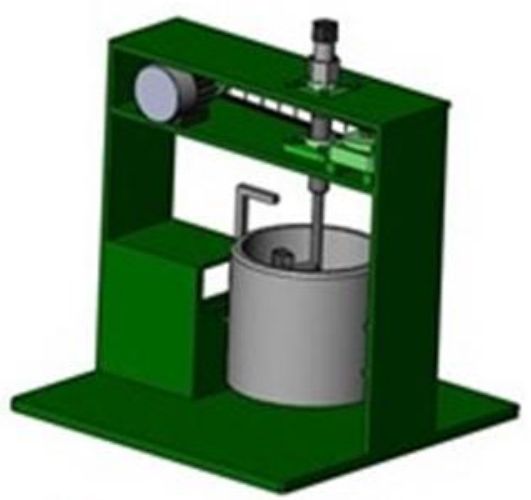

GAMBAR 3. Alat PSJ (Pengolah Serbuk Jahe tampilan 3D)

\section{Manufaktur}

Urutan proses pengerjaan rancang bangun adalah sebagai berikut:

1. Pengerjaan desain

2. Pengerjaan rangka mesin produksi

3. Pengerjaan tabung pemasakan

4. Pengerjaan poros pengaduk

5. Perakitan antar komponen

Tahapan rancang bangun mesin produksi jahe merah serbuk adalah sebagai berikut:

\section{Persiapan Bahan}

1. Persiapan bahan yang akan digunakan yaitu menggunakan besi siku $4 \times 4 \mathrm{~cm}$, plat stainless foodgrade $120 \times 240 \mathrm{~cm}$, pipa stainless foodgrade 1 inch, pipa stainless foodgrade 1,75-inch, gearbox tipe 60 rasio 1:60, motor listrik 1/4 hp. Penggunaan material stainless steel mengacu pada penelitian Febriyanto dan Budijono, 2015 yang menggunakan material yang sama untuk membuat tempat pengadukan untuk petis untuk tahu. Material ini memiliki keunggulan transfer panas yang merata dan tidak mudah berkarat.

2. Penandaan material (marking) dilakukan dengan menggunakan meteran dan penggaris siku serta spidol warna putih. Pemotongan dan penyambungan dilakukan menggunakan mesin gerinda potong (Gambar 3)

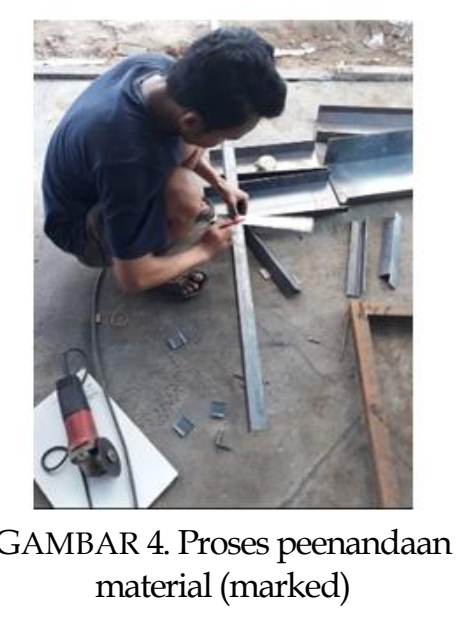

3. Pemotongan besi siku untuk membuat rangka Proses pemotongan besi siku dilakukan dengan menggunakan gerinda tangan yang sudah disesuaikan dengan ukuran pada desain.

\section{Penyambungan Material}

Pada penyambungan rangka digunakan metode pengelasan las listrik namun pada penyambungan tabung pemasakan yang berbahan material stainless menggunakan las MIG (Metal Inert Gas Welding). Proses ini dapat dilihat pada Gambar 5.

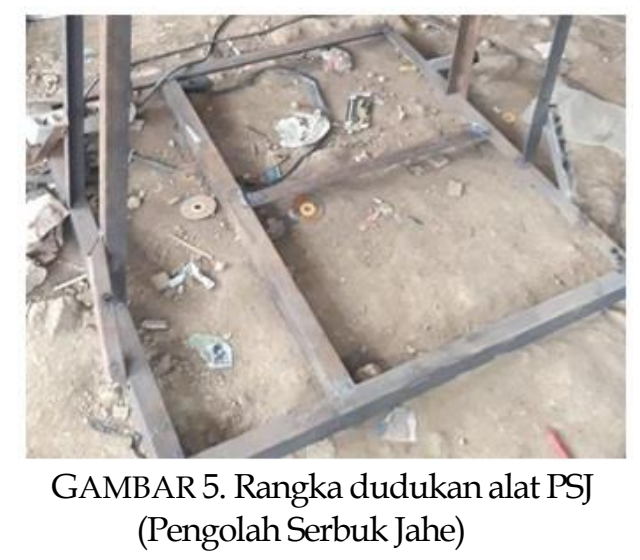




\section{Finishing alat PSJ (Pengolah Serbuk Jahe)}

Proses pemotongan dan penyambungan material untuk komponen yang telah selesai dilanjutkan dengan penghalusan bekas las-lasan dengan menggunakan kikir dan gerinda batu. Pemberian lubang untuk dudukan mesin dan gearbox. Proses selanjutnya adalah pemberian lubang pada benda kerja. Alat yang digunakan adalah bor listrik. Ukuran bor yang digunakan adalah $14 \mathrm{~mm}$ dan $22 \mathrm{~mm}$.
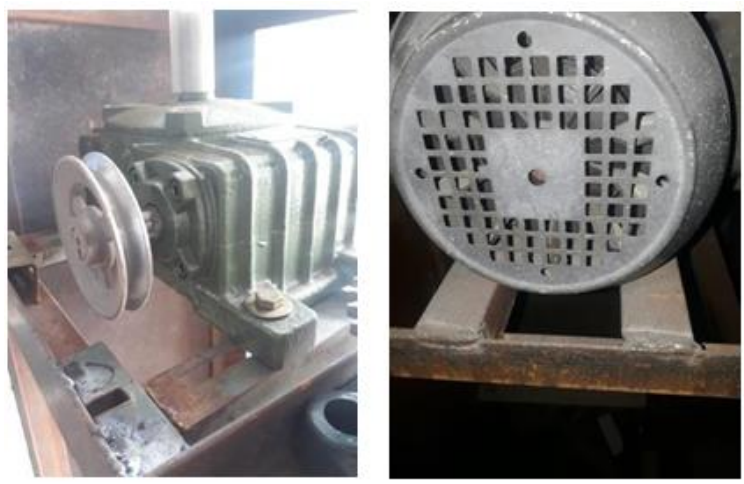

GAMBAR 6. Gearbox, poros, pulley (kiri) dan motor listrik AC (kanan)

\section{Perakitan dan Proses Kerja Mesin}

Pemberian lubang pada dudukan mesin dan gearbox yang telah selesai dikerjakan dilanjutkan dengan merakit atau menghubungkan komponen satu dengan komponen lainnya. Proses pembuatan rancang bangun mesin produksi jahe merah serbuk dibagi menjadi 3 bagian yaitu, pembuatan rangka, pembuatan poros pengaduk, dan pembuatan tangki pemasakan ektrak jahe. Kemudian dari proses tersebut bisa dirangkai menjadi satu bagian sehingga terbentuk mesin produksi jahe merah.

Proses kerja dari mesin produksi serbuk jahe merah yaitu melalui proses perpindahan tenaga dari motor listrik $1 / 4 \mathrm{Hp}$ dengan luaran awal 1400 rpm (Samhuddin et al., 2018) kemudian diteruskan ke gearbox (speed reducer) melalui pulley dan $v$-belt. Setelah itu diteruskan ke poros tengah yang sudah dibuatkan dudukan dengan bearing melalui perantara gear, dan langkah terakhir putaran dari poros tengah diteruskan ke poros pengaduk melalui sistem penguncian menggunakan bantuan mur 26 dan dudukan mur pada poros tengah (Mustofa dan Botutihe, 2019). Penguncian poros yang dapat dibuka dan dipasang secara manual mempermudah dalam pencucian alat pengaduk setelah digunakan.

\section{PROSES PENGOLAHAN JAHE MERAH SERBUK}

\section{Pendidihan Jahe}

Proses kerja pada mesin produksi jahe merah serbuk menghasilkan data berupa waktu yang dibutuhkan dari awal proses pemasakan yang masih berupa cairan ekstrak jahe hingga menjadi serbuk jahe.

1. Pada menit 0-10 adalah proses pemanasan minyak hingga mendidih yang ada didalam tangki pemasakan dengan volume minyak 5 liter atau $1 / 4$ dari ketinggian tangki. Pengadukan berlangsung pada kecepatan 150 rpm. Putaran yang terlalu cepat maka serbuk Jahe kualitasnya kurang baik dan apabila terlalu lambat maka akan menggumpal atau mengkristal (Fatchurrochman dan Sydore, 2018)

2. Menit 15-45 cairan ekstrak jahe sudah mulai mendidih yang diakibatkan dari proses pemasan dari kompor yang disalurkan melalui panas minyak yang relatif lebih stabil panasnya.

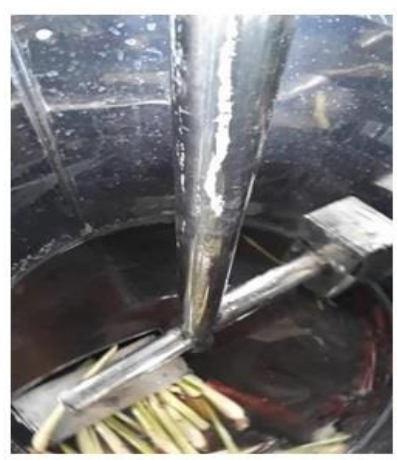

GAMBAR 7. Poros pengaduk pada alat PSJ (Pengolah Serbuk Jahe)

\section{Proses Buih dan Pasta pada Jahe}

Langkah berikutnya pada menit $60-80$ cairan jahe sudah mulai mengeluarkan buih busa yang menjadi tanda bahwa proses kristalisasi sedang berlangsung (Gambar 8a). Pada menit ini proses keringnya cairan ekstrak jahe sudah mulai kelihatan pada dinding tangki. Penyusutan volume carian tersebut terjadi pada rentang 90110 menit. Cairan ekstrak jahe sudah mulai mengalami penyusutan dan perubahan bentuk menjadi pasta (Gambar 8b). Proses berikutnya pada menit ke 120-150 kembali mengalami proses pemuaian dengan 
ditandai volume pasta jahe merah mulai mengalami pemuaian.
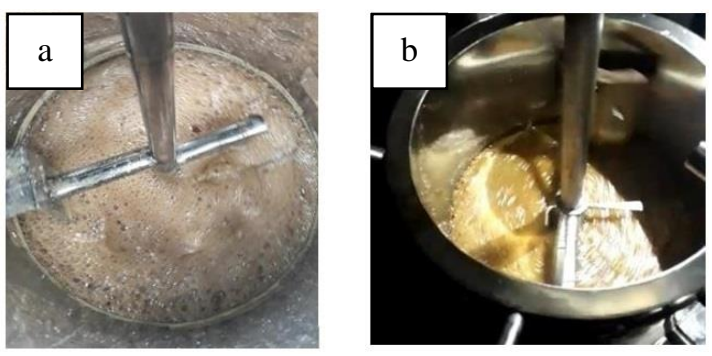

GAMBAR 8. Gearbox, poros, dan pulley (kiri) dan motor listrik AC (kanan)

\section{Pemuaian}

Pada proses akhir ini menit 150-160 mulai terbentuk serbuk jahe merah setelah proses pemuaian yang terakhir kemudian menyusut dan berubah menjadi serbuk.

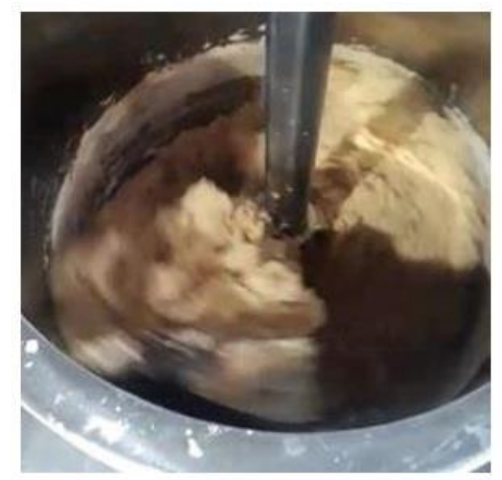

GAMBAR 9. Serbuk Jahe merah masih dalam kondisi pendinginan

\section{Pendinginan}

Langkah terakhir yaitu pada menit 160-180 sebaiknya api pada kompor dikecilkan agar serbuk jahe tidak gosong, dengan kondisi mesin produksi tetap menyala agar terjadi proses pendinginan dan granula-granula tidak terbentuk dan poros tetap dalam kondisi berputar (Gambar 9). Reklistalisasi dan perubahan karakterisitk fisis Jahe secara berurutan ditampilkan pada Gambar 10 dan 11. Proses pembuatan Jahe dalam bentuk serbuk ini dapat memperpanjang masa kedaluwarsa produk yang apabila dalam kondisi cair dalam bentuk sirup Jahe hanya bertahan 4 bulan dengan adanya rekayasa berbentuk serbuk Jahe mampu bertahan lebih lama yaitu 10 bulan.
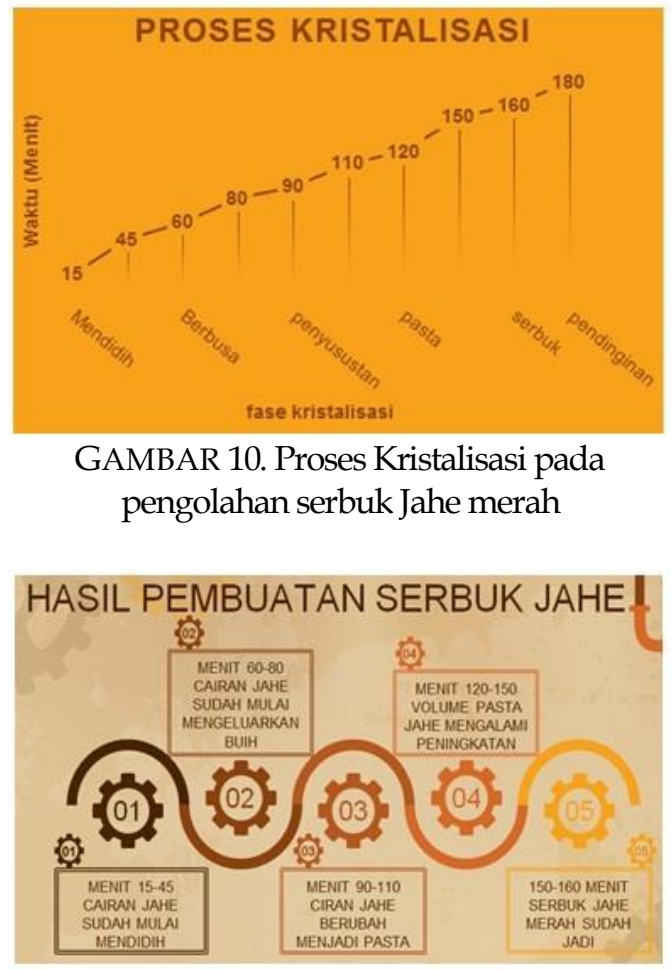

GAMBAR 11. Hasil pembuatan serbuk Jahe merah

\section{KESIMPULAN}

Hasil pembuatan serbuk jahe melalui proses yang cukup lama yaitu, pemanasan minyak yang ada didalam tangki pemasakan, kemudian panas tersebut menjadi perantara untuk memanaskan cairan ekstrak jahe yang ada didalam tangki pemasakan dan membutuhkan waktu \pm 180 menit dari proses awal pemanasan hingga menjadi serbuk jahe merah. Alat PSJ ini mampu menggantikan proses pengadukan manual dan mengurangi residu berupa gumpalan jahe. Hasil serbuk Jahe merah yang dihasilkan lebih banyak $30 \%$ dibandingkan dengan proses manual.

\section{DAFTAR PUSTAKA}

Bureau of Energy Efficiency, 2004. Energy Efficiency in Electrical Utilities.

Efendi, A., Nugroho, Y.S. and Fahmi, M., 2020. Perancangan Rangka dan Analisis Beban Mobil Listrik Sula Menggunakan Software Autodeks Inventor. Jurnal EKomtek (Elektro-Komputer-Teknik), 4(1), pp.100-114.

Etwin Fibrianie, S., Cahyadi, D. and Hidayanto, A.F. 2018, Rancang Bangun Mesin Penggiling Dan Potong Kerupuk Ikan 
Dengan Menggunakan Gearbox. Journal Teknologi Industri, 12(1), 1-8.

Fatchurrochman, M. and Sydore, F.R., 2018. Mesin Kristalisasi Serbuk Untuk Ukm Jamu Varagus Di Kecamatan Pegandon Kendal. Rekayasa: Jurnal Penerapan Teknologi dan Pembelajaran, 15(2), pp.82-88.

Febriyanto, D. dan Budijono, A.P., 2015. Rancang Bangun Mesin Pengaduk Petis Semi Otomatis. Journal of Education Technology Students, 2(03).

Hariyanto, S.D., Papasi, R.G., Munthohani, G.R., Lanekri, I.T. and Sastika, I.P., 2020. Perancangan dan Fabrikasi Mesin Pengolah Ubi Kayu untuk Produksi Makanan Ringan Lanting Kapasitas 40 kg/jam. Quantum Teknika: Jurnal Teknik Mesin Terapan, 2(1), pp.38-46.

Mustofa, M. and Botutihe, S., 2019. Rancang Bangun Dan Pengujian Alat Pengaduk Dodol. Jurnal Teknologi Pertanian Gorontalo (JTPG), 4(1), pp.26-33.

Samhuddin, S., Hasbi, M. and Jamiluddin, J., Perencanaan Sistem Transmisi Alat Peniris Pada Mesin Pengering Helm. ENTHALPY, 3(1).

Setyaningrum, R. and Lestari, K.P., 2020. Rancang Bangun Alat Produksi” Bandrek" Untuk Mengoptimalkan Proses Kristalisasi Dan Meminimalkan Residu Produk. Simetris: Jurnal Teknik Mesin, Elektro dan Ilmu Komputer, 11(1), pp.5154.

Yudha, V. and Nugroho, N., 2020. Rancang Bangun Mesin Perajang Singkong dengan Pendorong Pegas. Quantum Teknika: Jurnal Teknik Mesin Terapan, 2(1), pp.20-26.

Yulianto, M.E., Handayani, D., Puspitarini, A.S., Nugraheni, F.S. and Yanti, N.R., 2018. Pembuatan Serbuk Jahe Instan Dengan Metode Kristalisasi Guna Meningkatkan Perekonomian Warga RW. 05 Kelurahan Tembalang, Semarang. SNKPPM, 1(1), pp.44-46. 